\title{
DIFFERENCES IN THE DEVELOPMENT OF TACTILE FUNCTIONS IN PARTIALLY SIGHTED CHILDREN IN RELATION TO CATEGORY AND TYPE OF VISUAL IMPAIRMENT
}

\author{
Dženana Radžo Alibegović ${ }^{1}$ \\ Aldijana Kudumović
}

Original scientific paper

Faculty of Education and Rehabilitation, University of Tuzla, Bosnia and Herzegovina Public Institution "School for the Education and Rehabilitation of People with Psycho-physical Disabilities" Zenica

Received: $2019 / 6 / 18$

Accepted: 2019/8/30

\begin{abstract}
The aim of this study was to examine the differences in the development of tactile functions in visually impaired (amblyopic) children in relation to the category and type of visual impairment. In the study, 30 respondents with visual impairment, aged 7-13 and of both genders were examined. Tactile functions assessment was performed using the LuriaNebraska Tactile Functions Assessment Scale ('C3'). A t-test was used to examine the significance of arithmetic mean differences. With respect to the category of visual impairment, it was found that there were statistically significant differences in arithmetic means on three variables of tactile perception. Respondents have equally developed tactile functions in relation to the type of visual impairment.
\end{abstract}

Key words: children with visual impairment, tactile functions

\section{INTRODUCTION}

Studies have shown that the existence of visual impairment limits early child development in a complex way (Reynell, 1978; Sonksen, Levitt, \& Kitzinger, 1984). Limitations relate to the integration and interpretation of perception from other sensory organs, the development of emotional connection, personality and confidence, social skills, localization of sound and tactile sensations, fine- and gross motor skills, persistence of objects, development of language and other cognitive concepts (Sonksen, Levitt, \& Kitzinger, 1984; Sonksen, 1983; Sonksen \& Dale 2002; Alimovic, 2009).
Tactile - kinesthetic perception is of great importance for blind children because it represents a compensatory mechanism for the lack of visual perception. Barraga (1986) states, that the sense of touch is the dominant channel for obtaining information in blind children. However, in order for a blind person to establish a quality connection with reality, it is necessary to associate the sense of touch with kinesthetic sensitivity. She linked the two modalities by pointing out the links between tactility and kinesthesia in seeking and providing information to the brain, then encrypting, connecting and interpreting it.

\footnotetext{
${ }^{1}$ Correspondence to:

Dženana Radžo Alibegović, Faculty of Education and Rehabilitation, University of Tuzla, Bosnia and Herzegovina

75000 Tuzla, Bosnia and Herzegovina

E-mail:dzenana.radzo@untz.ba
} 
Unlike the visual, tactile - kinesthetic perception is based on direct contact. Accordingly, Jablan (2007) states, that many objects and phenomena that cannot be contacted directly are not accessible to the perception of blind people. Although this information is less accurate than visual information and may be short-lived and often volatile, Stancic (1991) emphasizes the importance of stimulating this system in children with visual impairments. Visually impaired students use tactile and kinesthetic input to learn about their environment. Such input should not be regarded as a " smaller sense " used instead of sight, but should be regarded as another learning aid system (Cox \& Dykes, 2001).

According to Lukic (2007), it is essential that the child learns to use its hands. Jablan (2010) points out, that passive movements are very important for the development of tactile - kinesthetic perception of blind children, i.e. the hand movements of a blind child led or directed by another person. Such movements are the basis for acquiring tactile - kinesthetic experience, and therefore tactile - kinesthetic learning. Kinesthesia plays an important role in any motor skill learning because it indicates position and movement and integrates all sensory-motor experiences from earlier stages of development.

Tactile functions encompass an entire complex of functions related to the detection of simple elements of tactile sensation and sensitivity, and the sequential analysis and integration of these elements into a meaningful pattern (Golden, 1987; Lević, 1988; Ocić, 1988). The aim of this study was to examine whether there are differences in the development of tactile function in visually impaired children in relation to the category and type of visual impairment.

\section{METHODS}

\section{Sample respondents}

The sample consisted of 30 respondents with visual impairment, elementary school age, aged 7-13, both genders, institutionally accommodated at the "Center for Blind and Partially Sighted Children and Youth" Nedžarići - Sarajevo, and of children with visual impairment who attend regular school, i.e. "The First Elementary School" in Zavidovići.

Respondents from our sample according to visual acuity were classified into two categories:

- I category - severe visual impairment with a visual acuity below 0.1

- II category - lighter forms of visual impairment with visual acuity $0.3-0.8$.

Figure 1 shows the distribution of respondents in relation to the category of visual impairment. The results obtained in Figure 1 show that a higher percentage of visually impaired respondents fall into the lighter category $(66.7 \%)$, while $33.3 \%$ of the respondents fall into the severe visual impairment category.

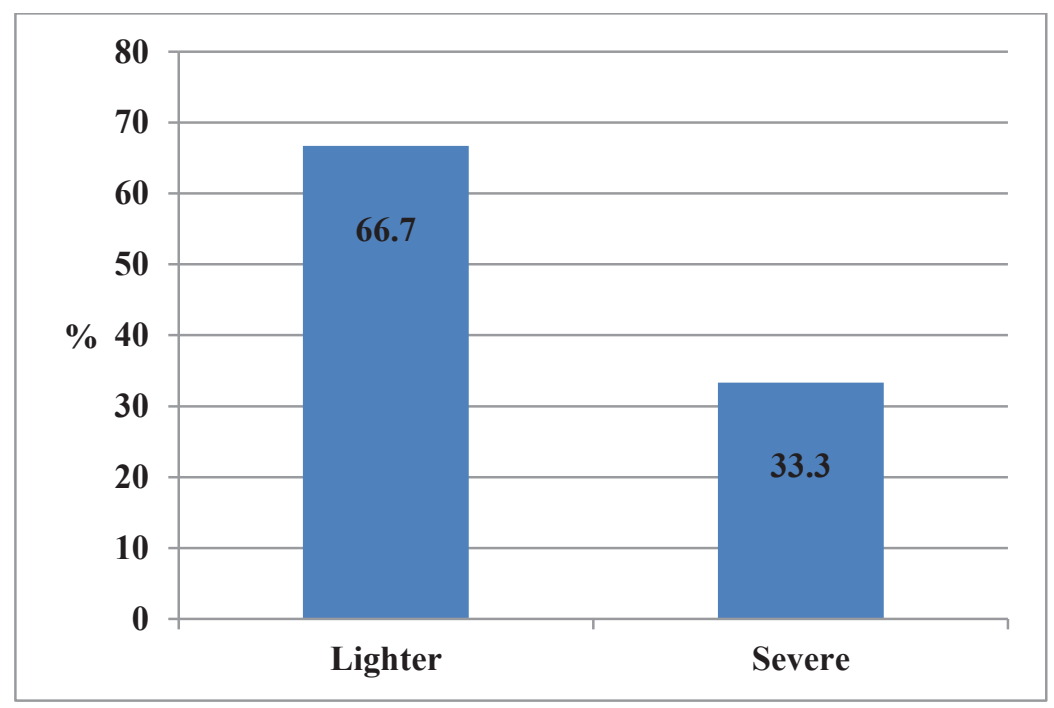

Figure 1. Distribution of respondents in relation to the category of visual impairment

In relation to the type of visual impairment, of the 30 respondents with visual impairment, $53.3 \%$ had functional - and $46.7 \%$ of the respondents had organic visual impairment (Figure 2). The results of the Chi-square test showed that there was no statistically significant difference in the distribution of respondents in relation to the category of visual impairment $(\chi 2=3.33 ; p=.068$ and the type of visual impairment $(\chi 2=.13 ; \mathrm{p}=.715)$. 


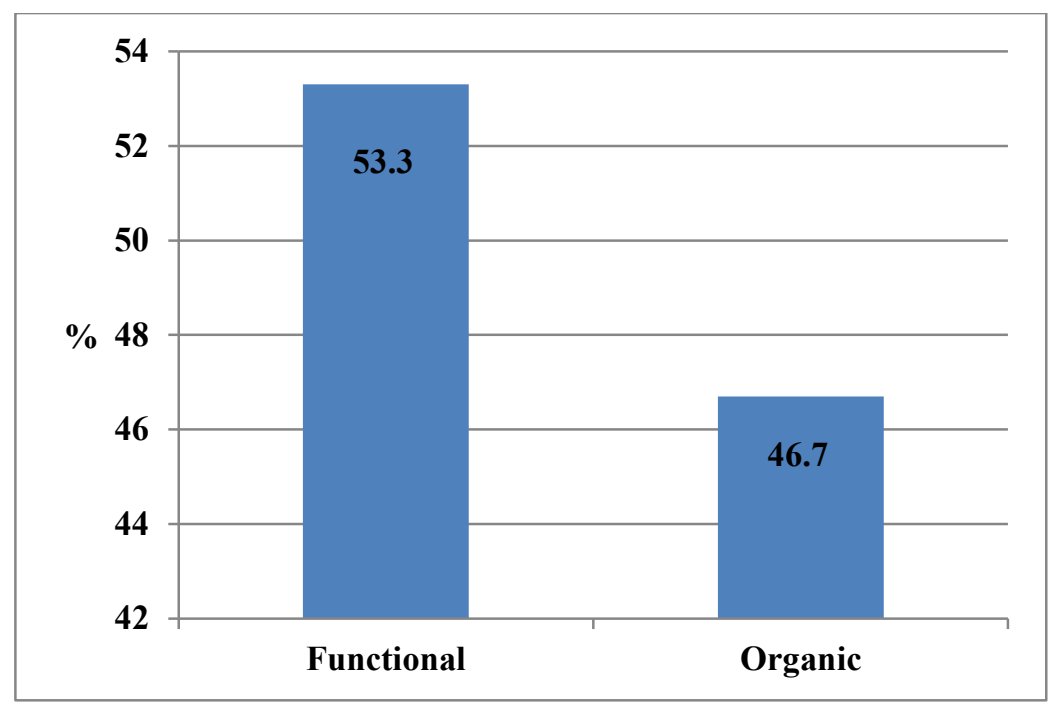

Figure 2. Distribution of respondents in relation to the type of visual impairment

\section{Sample variables}

\section{Anamnestic variables}

1. visual acuity

2. type of visual impairment.

\section{Variables for testing tactile functions}

- ability to localize touch

- sensitivity to pain

- the ability of specific tactile sensitivity, i.e. pressure strength discrimination

- ability to discriminate two points

- ability to differentiate tactile forearm sensations

- ability to differentiate and identify geometric figures drawn on the respondents' hand

- ability to discriminate and identify numbers written on the skin of the respondent

- stereognosis ability, i.e. tactile recognition of known objects without the involvement of the eyesight

\section{Measuring instrument}

The Luria-Nebraska Tactile Functions Assessment Scale "C3" was used to assess tactile functions. It is one of the scales included in the Luria-Nebraska Neuropsychological Battery for Children (LNNBC) (Golden, 1987). It contains 16 particles grouped into pairs (the same task is performed using the right and left hand).

\section{The method of conducting research}

The research was conducted at the "First Elementary School" in Zavidovići and the "Center for Blind and Partially Sighted Children and Youth" Nedžarići - Sarajevo. All respondents were examined individually in a separate room and in a comfortable environment. The test sequence of tactile functions was designed in such a way as to prevent sequential activation of the same set of dimensions to avoid the effects of saturation and possible negative transfer.

\section{Data processing methods}

After the research, the obtained data were processed by the computer statistical program SPSS 17.0 for the Microsoft Windows operating system. Basic statistical parameters were calculated: minimum and maximum results, arithmetic mean and standard deviation. To determine the significance of differences in arithmetic means of observed variables of tactile perception between the two groups of respondents, a $t$-test for the independent sample at the significance level of $5 \%$ was used. The distribution of respondents according to the test results is presented in frequencies. 


\section{RESULTS AND DISCUSSION}

Testing the differences of tactile perception variables in relation to the type of visual impairment

The results of the t-test stated in Table 1 show that there is a statistically significant difference with respect to the type of visual impairment and the variable "Graphesthesia-Numbers". Based on the insight into the values obtained, it can be concluded that children with functional visual impairment at the significance level of .05 perform better on the variable "Graphesthesia-Numbers" compared to children with organic visual impairment. Children with organic vision impairment perform better on the variables "Topognosis" and "Discrimination of two points". Although there are differences in the devel- opment of tactile perception between children with functional - and organic visual impairment, they are not statistically significant. Research findings related to tactile perception in relation to the type of visual impairment showed that respondents with functional and organic visual impairment had equally developed tactile functions. These results tell us that the primary cognition path of our respondents is the tactile path, and that regardless of the percentage of their eyesight, these children are educated by the methods for the blind. The author Radžo Alibegović (2013) examined the difference of tactile perception in relation to the type of visual impairment on a sample of 35 respondents with visual impairment. She found that there were no statistically significant differences in tactile function relative to the type of visual impairment.

Table 1. Testing the differences of individual variables of tactile perception in relation to the type of visual impairment

\begin{tabular}{|c|c|c|c|c|c|}
\hline Variables & $\begin{array}{l}\text { Type of visual } \\
\text { impairment }\end{array}$ & Mean & SD & $t$ & $p$ \\
\hline \multirow{2}{*}{ Topognosis } & Functional & .81 & 1.37 & \multirow{2}{*}{.05} & \multirow{2}{*}{.956} \\
\hline & Organic & .78 & 1.25 & & \\
\hline \multirow{2}{*}{ Sensitivity to pain } & Functional & .06 & .25 & \multirow{2}{*}{-1.70} & \multirow{2}{*}{.099} \\
\hline & Organic & .64 & 1.33 & & \\
\hline \multirow{2}{*}{$\begin{array}{l}\text { Pressure strength } \\
\text { discrimination }\end{array}$} & Functional & .43 & .96 & \multirow{2}{*}{-.37} & \multirow{2}{*}{.714} \\
\hline & Organic & .57 & 1.01 & & \\
\hline \multirow{2}{*}{ Discrimination of two points } & Functional & 1.25 & 1.18 & \multirow{2}{*}{.50} & \multirow{2}{*}{.617} \\
\hline & Organic & 1.00 & 1.51 & & \\
\hline \multirow{2}{*}{$\begin{array}{l}\text { Differentiation of tactile } \\
\text { forearm sensations }\end{array}$} & Functional & .00 & .00 & \multirow{2}{*}{-} & \multirow{2}{*}{-} \\
\hline & Organic & .00 & .00 & & \\
\hline \multirow{2}{*}{ Graphestesia-Figures } & Functional & .31 & .60 & \multirow{2}{*}{-1.53} & \multirow{2}{*}{.136} \\
\hline & Organic & .71 & .82 & & \\
\hline \multirow{2}{*}{ Graphestesia-Numbers } & Functional & .31 & .70 & \multirow{2}{*}{-2.46} & \multirow{2}{*}{.020} \\
\hline & Organic & 1.42 & 1.65 & & \\
\hline \multirow[t]{2}{*}{ Stereognosis } & Functional & .12 & .50 & \multirow{2}{*}{-.45} & \multirow{2}{*}{.654} \\
\hline & Organic & .21 & .57 & & \\
\hline
\end{tabular}

Testing the differences of tactile perception variables in relation to the category of visual impairment

Table 2 shows the results of the t-test in relation to the development of tactile perception variables and the category of visual impairment of children with visual impairment. Based on the results of the t-test, it can be concluded that there is a statistically signif- icant difference on three observed variables of tactile perception. These are the variables "Sensitivity to pain", "Graphesthesia-Figures", and the variable "Graphesthesia-Numbers". The results of the t-test show that, at a level of statistical significance of .05 , respondents of the lighter visual impairment category achieved better scores on the variables "Sensitivity to pain" and "Graphesthesia" compared to respondents of the severe visual impairment category. 
Also, respondents with lighter visual impairment at a statistical significance level of 0.01 achieved better results on the variable "Graphesthesia-Numbers" compared to those with severe visual impairment.

In her research, Jablan (2001) examined the impact of the visual impairment category on tactile functions in children with visual impairment. A total of 95 respondents were included: 46 totally blind and 49 practically blind respondents. She concluded that the ability to differentiate tactile sensations on the left forearm, the ability to differentiate and identify geometric figures drawn on the hand (right and left), and the ability to discriminate and identify numbers written on the skin (right and left side) are significantly better developed in practically blind respondents in relation to the totally blind.

Heller $(1985,1989)$ found that individuals, who were always blind, were as successful in tactile perception as individuals who lost their eyesight later, leading her to conclude that visual experience was not necessary for tactile perception. Knowledge of Braille is not a guarantee for the correct representation of tactile images, although tactile skills and experience of tactile perception have an impact. She had previously concluded that the simultaneous use of eyesight and touch by the visually impaired improves the recognition of tactile patterns; she suggested that visually impaired people use eyesight to conduct tactile research.

Table 2. Differences in the development of tactile perception in relation to the category of visual impairment (t-test)

\begin{tabular}{|c|c|c|c|c|c|}
\hline Variables & $\begin{array}{l}\text { Category of visual } \\
\text { impairment }\end{array}$ & Mean & SD & $t$ & $p$ \\
\hline \multirow{2}{*}{ Topognosis } & Lighter & .65 & 1.26 & \multirow{2}{*}{-.89} & \multirow{2}{*}{.380} \\
\hline & Severe & 1.10 & 1.37 & & \\
\hline \multirow{2}{*}{ Sensitivity to pain } & Lighter & .05 & .22 & \multirow{2}{*}{-2.48} & \multirow{2}{*}{.019} \\
\hline & Severe & .90 & 1.52 & & \\
\hline \multirow{2}{*}{$\begin{array}{l}\text { Pressure strength } \\
\text { discrimination }\end{array}$} & Lighter & .55 & 1.05 & \multirow{2}{*}{.39} & \multirow{2}{*}{.698} \\
\hline & Severe & .40 & .84 & & \\
\hline \multirow{2}{*}{ Discrimination of two points } & Lighter & 1.10 & 1.16 & \multirow{2}{*}{-.19} & \multirow{2}{*}{.850} \\
\hline & Severe & 1.20 & 1.68 & & \\
\hline \multirow{2}{*}{$\begin{array}{l}\text { Differentiation of tactile } \\
\text { forearm sensations }\end{array}$} & Lighter & .00 & .00 & \multirow{2}{*}{-} & \multirow{2}{*}{-} \\
\hline & Severe & .00 & .00 & & \\
\hline \multirow{2}{*}{ Graphestesia-Figures } & Lighter & .30 & .57 & \multirow{2}{*}{-2.26} & \multirow{2}{*}{.031} \\
\hline & Severe & .90 & .87 & & \\
\hline \multirow{2}{*}{ Graphestesia-Numbers } & Lighter & .35 & .74 & \multirow{2}{*}{-3.20} & \multirow{2}{*}{.003} \\
\hline & Severe & 1.80 & 1.75 & & \\
\hline \multirow{2}{*}{ Stereognosis } & Lighter & .10 & .44 & \multirow{2}{*}{-.97} & \multirow{2}{*}{.339} \\
\hline & Severe & .30 & .67 & & \\
\hline
\end{tabular}

\section{CONCLUSION}

Based on the analysis of the obtained research results, it can be concluded that:

- There are statistically significant differences of the arithmetic mean on three variables of tactile perception in relation to the category of visual impairment. These are the variables "Sensitivity to pain", "Graphesthesia", and the variable "Graphesthesia-Numbers".
- Research findings related to tactile perception with respect to the type of visual impairment showed that respondents with functional and organic visual impairment had equally developed tactile functions.

- Regardless of the percentage of eyesight, the primary path in receiving information of our respondents is the tactile path, implying that these children were educated by methods for the blind. 


\section{REFERENCES}

Alimović, S. (2009). Temelji razvoja emocija kod djece s oštećenjem vida. S Vama; 7/8, 27-34.

Barraga, N.C. (1986). Sensory perceptual development. In G.T. Scholl (Ed.), Foundations of education for blind and visually handicapped children and youth: Theory and practice. NY: American Foundation for the Blind.

Cox, P.R., \& Dykes, M.K. (2001). Effective classroom adaptations for students with visual impairments. Teaching Exceptional Children, 33(6), 68-74.

Golden, J.C. (1987). Luria-Nebraska Neuropsychological Battery. Children's Revision, Manual. Los Angeles: Western Psychological services.

Heller, M.A (1985). Tactual perception of embossed Morse code and braille: The alliance of vision and touch. Perception $14,563-570$.
Heller, M. A. (1989). Texture perception in sighted and blind observers. Perception and Psychophysics, 45, 49-54.

Jablan, B. (2007). Motorne i taktilne funkcije kod slepe dece. Fakultet za specijalnu edukaciju i rehabilitaciju, CID, Beograd.

Jablan, B. (2010). Čitanje i pisanje Brajevog pisma. Beograd: Univerzitet u Beogradu, Fakultet za specijalnu edukaciju i rehabilitaciju.

Jablan, B. (2001). Taktilne i kinestetičke funkcije u procesu opažanja prostora slijepe djece. Doktorska disertacija. Defektološki fakultet, Beograd.

Lukić, A. (2007 ). Učenik s oštećenjem vida u redovitoj školi. Zagreb: Hrvatski savez slijepih.

Lević, Z. (1998). Osnovi savremene neurologije. Beograd: Zavod za udzbenike i nastavna sredstva.

Ocić, G. (1998). Klinička neuropsihologija. Beograd: Zavod za udžbenike i nastavna sredstva. 